\title{
Response of Different Varieties of Carnation (Dianthus caryophyllus L.) to Different Types of Pinching
}

\author{
Suraksha Rai* and Urfi Fatmi \\ Department of Horticulture, Sam Higginbottom University of Agriculture, Technology and \\ Sciences, Prayagraj, India \\ *Corresponding author
}

\begin{tabular}{|l|}
\hline Ke y w or d s \\
Carnation, \\
Varieties, Pinching, \\
Interaction
\end{tabular}

\begin{abstract}
A B S T R A C T
An experiment entitled "Response of different varieties of carnation (Dianthus caryophyllus L.) to different types of pinching" was conducted in naturally ventilated polyhouse, Department of Horticulture, Naini Agricultural Institute, Sam Higginbottom University of Agriculture, Technology And Sciences, Prayagraj. The experiment was conducted in Factorial Randomized Block Design (FRBD) with five varieties replicated thrice. The varieties used were White Liberty, Marvellous, Purple Sky, Vanity and Baltico. The results revealed that the variety Baltico was found to be the most promising variety with respect to maximum no. of leaves (165.68), maximum flower diameter $(7.42 \mathrm{~cm})$ and maximum vase life (9.56 days). Among pinching, single pinching was found to be the most efficient because the single pinched plants were significantly taller $(90.35 \mathrm{~cm})$, bore maximum number of leaves $(182.73)$, maximum plant spread $(25.17 \mathrm{~cm})$, earliness in bud initiation (91.4 days), maximum flower diameter $(7.19 \mathrm{~cm})$, maximum flower stalk length $(86.6 \mathrm{~cm})$ and had maximum vase life (8.33). Among interaction, maximum plant height $(102.60 \mathrm{~cm})$ was recorded in treatment combination of V4 x P1 (Vanity X single pinching), maximum no. of leaves (194.00) was recorded in V5 x P1 (Baltico X single pinching), maximum flower diameter $(8.03 \mathrm{~cm})$ was recorded in V5 X P1 (Baltico X single pinching) and maximum vase life (10.67 days) was recorded in treatment combination of V5 x P1 (Baltico X single pinching).
\end{abstract}

\section{Introduction}

Carnation (Dianthus caryophyllus L.), belonging to the family Caryophyllaceae is one of the most important cut flower in the world. It accounts for almost $50 \%$ of world cut flower trade along with roses and chrysanthemum. The flowers are known for their wide range of forms and colours, have an excellent keeping quality and have ability to rehydrate after long distance transportation. To produce quality flowers, carnation needs to be grown under cover in polyhouses (Ryagi et al., 2007).

Apical dominance is one of the serious problems for commercial carnation growers, as it does not permit lateral buds to develop, resulting in limited number of lateral branches and flowers (Pathania et al., 2000). Pinching 
is one of the most important cultural operations in carnation under protected cultivation. Pinching has direct relationship with production of flower and regulation of flowering for successful marketing (Dalal et al., 2006). In pinching, terminal growing shoots about $2-3 \mathrm{~cm}$ long is removed to overcome apical dominance and to promote side branching, when the plants are of 6-8 leaf pair stage. When the plant attains 5 nodes, the first pinch is given, known as 'single pinch'. This would give rise to 6 lateral shoots.

With 'pinch and a half', 2-3 lateral shoots are pinched again. For 'double pinch', all the lateral shoots are pinched off. Depending on the need of crop spread, single pinch, pinch and a half or double pinch is given. Single pinch is done for early flower production, pinch and a half is done to increase the duration of flowering and provides steady production of flowers without any peak time and double pinching is done to delay flowering period.

\section{Materials and Methods}

An experiment entitled Response of different varieties of Carnation (dianthus caryophyllus 1.) to different types of pinching, was carried out in naturally ventilated polyhouse under Prayagraj agro climatic condition in the Department of Horticulture, Sam Higginbottom University of Agriculture, Technology And Sciences during November 2019 - May 2020. Rooted terminal cuttings were planted in raised beds of $6 \mathrm{~m}$ length, 0.8 $\mathrm{m}$ width, $30 \mathrm{~cm}$ height and with a spacing of $20 \mathrm{~cm}$ between the rows and $20 \mathrm{~cm}$ apart. There were 15 treatment combinations consisting of five varieties viz.

White Liberty (V1), Marvellous (V2), Purple Sky (V3), Vanity (V4) and Baltico (V5) and three types of pinching i.e., single pinch (P1), pinch and half (P2) and double pinch (P3).
The experiment was laid out in Factorial Randomized Block Design (FRBD) with three replications.

Single pinch was given when the plants attained 6 nodes i.e. about 30 days after planting. Pinching was done at the $6^{\text {th }}$ node, it gave rise to 5-6 lateral shoots. Again, after 55 to 60 days, "pinch and a half" was done in which 2-3 lateral shoots were pinched off again. For "double pinch", all the lateral shoots were pinched off.

\section{Results and Discussion}

The data presented in Table 1 shows that the maximum plant height was recorded in variety Vanity $(92.38 \mathrm{~cm})$. Variability in plant height among the varieties prevails due to genetic nature, growing environmental conditions, production technology and cultural practices. Similar results were obtained by Bhalla et al., (2007); Gharge et al., (2011) and Singh et al., (2016) in carnation. Maximum number of leaves was recorded in variety Baltico (165.68). This might be due to taller plant with higher number of internodes and climatic condition inside the polyhouse favouring increased growth rate of plants. Similar results were obtained by Kamble (2001), Reddy et al., (2004) and Singh et al., (2016) in carnation.

Among pinching, single pinched plants were significantly taller $(90.35 \mathrm{~cm})$, bore maximum number of leaves (182.76) and maximum plant spread $(25.17 \mathrm{~cm})$. Variation in number of leaves might be due to taller plant and more number of internodes per stem. Similar results were obtained by Singh et al., (2016) in carnation. Maximum plant height was recorded in the treatment combination of V4 X P1 $(102.60 \mathrm{~cm})$, number of leaves in V5 X P1 (194.00) and plant spread in V3 X P1 $(27.6 \mathrm{~cm})$. 
Table.1 Effect of different types of pinching on plant height, no. of leaves and plant spread of different varieties of carnation

\begin{tabular}{|c|c|c|c|}
\hline \multirow{2}{*}{$\begin{array}{c}\text { Treatments } \\
\text { Varieties (V) }\end{array}$} & Plant height (cm) & No. of leaves & Plant spread (cm) \\
\hline & & & \\
\hline V1-White liberty & 71.59 & 154.44 & 21.76 \\
\hline V2- Marvellous & 80.22 & 154.93 & 22.47 \\
\hline V3- Purple sky & 71.58 & 149.17 & 24.64 \\
\hline V4- Vanity & 92.38 & 165.51 & 22.50 \\
\hline V5- Baltico & 64.94 & 165.68 & 21.82 \\
\hline C.D. & 1.35 & 1.74 & 0.75 \\
\hline $\mathrm{SE}(d)$ & 0.66 & 0.85 & 0.366 \\
\hline $\mathrm{SE}(\mathrm{m})$ & 0.47 & 0.59 & 0.26 \\
\hline \multicolumn{4}{|l|}{ Pinching (P) } \\
\hline P1- Single pinch & 90.35 & 182.76 & 25.17 \\
\hline P2-Pinch and a half & 71.62 & 154.41 & 22.90 \\
\hline P3- Double pinch & 66.45 & 136.67 & 19.84 \\
\hline C.D. & 1.05 & 1.35 & 0.58 \\
\hline SE (d) & 0.51 & 0.66 & 0.28 \\
\hline $\mathrm{SE}(\mathrm{m})$ & 0.36 & 0.46 & 0.20 \\
\hline \multicolumn{4}{|l|}{ Interaction (VXP) } \\
\hline V1 P1 & 87.83 & 186.00 & 23.93 \\
\hline V1 P2 & 67.87 & 148.67 & 22.17 \\
\hline V1 P3 & 59.07 & 128.67 & 19.17 \\
\hline P1 & 92.80 & 178.57 & 25.50 \\
\hline $\mathrm{V} 2$ & 75.80 & 151.23 & 23.53 \\
\hline V2 P3 & 72.07 & 135.00 & 18.37 \\
\hline V3 & 86.93 & 163.22 & 27.63 \\
\hline V3 P3 & 59.30 & 135.80 & 21.50 \\
\hline P1 & 102.60 & 192.03 & 24.70 \\
\hline V4 P2 & 87.83 & 166.82 & 22.37 \\
\hline P3 & 86.70 & 137.67 & 20.43 \\
\hline V5 P1 & 81.60 & 194.00 & 24.10 \\
\hline V5 & 58.10 & 156.83 & 21.63 \\
\hline V5 & 55.13 & 146.20 & 19.73 \\
\hline C.D. & 2.35 & 3.01 & 1.31 \\
\hline S.E. (d) & 1.14 & 1.47 & 0.63 \\
\hline S.E. (m) & 0.81 & 1.04 & 0.45 \\
\hline
\end{tabular}


Table.2 Effect of different types of pinching on earliness, flower diameter, stalk length and vase life of different varieties of carnation

\begin{tabular}{|c|c|c|c|c|}
\hline $\begin{array}{l}\text { Treatments } \\
\text { Varieties }(V)\end{array}$ & $\begin{array}{l}\text { Earliness in } \\
\text { bud } \\
\text { initiation } \\
\text { (days) }\end{array}$ & $\begin{array}{l}\text { Flower diameter } \\
(\mathbf{c m})\end{array}$ & $\begin{array}{l}\text { Stalk length } \\
\quad(\mathrm{cm})\end{array}$ & Vase life (days) \\
\hline V1-White liberty & 109.56 & 6.66 & 74.11 & 7.67 \\
\hline V2- Marvellous & 104.00 & 6.14 & 84.33 & 6.22 \\
\hline V3- Purple sky & 102.33 & 6.52 & 78.44 & 7.33 \\
\hline V4- Vanity & 107.78 & 6.71 & 85.22 & 8.56 \\
\hline V5- Baltico & 105.78 & 7.42 & 66.89 & 9.56 \\
\hline C.D. & 1.38 & 0.36 & 1.29 & 0.85 \\
\hline S.E. (d) & 0.67 & 0.18 & 0.62 & 0.41 \\
\hline S.E. (m) & 0.48 & 0.12 & 0.44 & 0.29 \\
\hline \multicolumn{5}{|l|}{ Pinching (P) } \\
\hline P1- Single pinch & 91.40 & 7.19 & 86.60 & 8.33 \\
\hline P2-Pinch and a half & 110.80 & 6.90 & 78.53 & 7.87 \\
\hline P3- Double pinch & 115.47 & 5.98 & 68.27 & 7.40 \\
\hline C.D. & 1.07 & 0.28 & 0.99 & 0.66 \\
\hline S.E. (d) & 0.52 & 0.14 & 0.48 & 0.32 \\
\hline S.E. (m) & 0.37 & 0.09 & 0.34 & 0.23 \\
\hline \multicolumn{5}{|l|}{ Interaction (VXP) } \\
\hline V1 P1 & 95.00 & 7.41 & 85.33 & 8.33 \\
\hline V1 P2 & 115.33 & 6.71 & 73.00 & 8.0 \\
\hline V1 P3 & 118.33 & 5.87 & 64.00 & 6.67 \\
\hline $\mathrm{V} 2$ & 92.67 & 6.23 & 92.67 & 6.33 \\
\hline $\mathrm{V} 2$ & 106.67 & 6.33 & 86.33 & 6.33 \\
\hline V2 P3 & 112.66 & 5.87 & 74.00 & 6.00 \\
\hline V3 & 87.33 & 7.37 & 88.67 & 7.67 \\
\hline V3 & 107.67 & 6.77 & 78.33 & 7.33 \\
\hline V3 P3 & 112.00 & 5.43 & 68.33 & 7.00 \\
\hline V4 & 96.00 & 6.93 & 92.00 & 8.66 \\
\hline V4 P2 & 111.00 & 6.97 & 86.00 & 8.33 \\
\hline V4 & 116.33 & 6.23 & 77.67 & 8.67 \\
\hline V5 P1 & 86.00 & 8.03 & 74.33 & 10.67 \\
\hline $\mathrm{P} 2$ & 113.33 & 7.73 & 69.00 & 9.33 \\
\hline V5 & 118.00 & 6.50 & 57.33 & 8.67 \\
\hline C.D. & 2.39 & 0.62 & 2.23 & N/A \\
\hline S.E. (d) & 1.16 & 0.30 & 1.08 & 0.72 \\
\hline S.E. (m) & 0.82 & 0.21 & 0.76 & 0.51 \\
\hline
\end{tabular}

Earliness in bud initiation was recorded in variety Purple Sky (102.33 days), maximum stalk length was recorded in variety Vanity $(85.22 \mathrm{~cm})$ and maximum flower diameter $(7.42 \mathrm{~cm})$ and vase life (9.56 days) were recorded in the variety Baltico. Variation in vase life among the varieties could be due to the ability of the varieties to produce ethylene and sensitivity to it. Among pinching, earliness in bud initiation (91.4 days), 
maximum stalk length $(86.6 \mathrm{~cm})$, flower diameter $(7.19 \mathrm{~cm})$ and vase life (8.33 days) were recorded in single pinched plants (Table 2).

Earliness in bud initiation and maximum stalk length in single pinched plants might be due to removal of the plant shoots only once. Flowers obtained from the single pinched plants have significantly longer stalk length which resulted in absorption more water from the vase, thus, resulting in longer vase life. The best treatment combination with regard to earliness in bud initiation (86.00 days), maximum flower diameter $(8.03 \mathrm{~cm})$ and maximum vase life (10.67 days) were recorded in V5 $\mathrm{X}$ P1 (Baltico $\mathrm{X}$ single pinching).

Based on findings of the experiment, it is concluded that the maximum no. of leaves (194.00), maximum flower diameter (8.03 $\mathrm{cm}$ ) and maximum vase life (10.67 days) was recorded in interaction between V5 $x$ P1 (Baltico $\mathrm{X}$ single pinching) making it the best treatment combination.

\section{References}

Bhalla, R. Dharma, S. Dhiman, SR and Jain, R. 2006. Effect of biofertilizers and biostimulants on growth and flowering in standard Carnation (Dianthus caryophyllus L.) J. Orn. Hort., 9 (4): 282-285.

Dalal, S.R., D.R. Nandre, S.G. Bharad, Swarupa Utgikar and R.D. Shinde (2006). Effect of pinching on carnation cv. YELLOW SOLAR under polyhouse condition. Internat. J. agric. Sci. Vol.2 No.2 July 2006: (356-357).

Gharge, C.P., G. Angadi, S., Basavaraj, N., and Patil, A., 2011. Performance of standard carnation (Dianthus caryophyllus L.) varieties under naturally ventilated polyhouse. Karnataka Journal of Agricultural Sciences 24(4): 487-489.

Pathania, N.S., Sehgal, O.P. and Gupta, Y.C. (2000). Pinching for flower regulation in Simcarnation. J. Orna. Hort., 3(2): 114-118

Ryagi, V. Y., S.M. Mantur and B. S. Reddy (2007). Effect of Pinching on Growth, Yield and Quality of Flowers of Carnation Varieties Grown under Polyhouse. Karnataka J. Agric. Sci., 20(4): (816-818) 2007.

Singh, Sandeep, Karetha, K.M. and Singh, Virendra (2016). Effect of pinching on growth of carnation varieties grown under protected condition. Asian J. Hort., 11(1): 119- 123, DOI: 10.15740/HAS/TAJH/11.1/119-123.

\section{How to cite this article:}

Suraksha Rai and Urfi Fatmi. 2020. Response of Different Varieties of Carnation (Dianthus caryophyllus L.) to Different Types of Pinching. Int.J.Curr.Microbiol.App.Sci. 9(11): 195-199. doi: https://doi.org/10.20546/ijcmas.2020.911.023 